\title{
Pedagogic commitment and prospects for integration of persons with disabilities into the labour market Roberta Caldin", Valeria Friso ${ }^{* *}$
}

\begin{abstract}
In this paper we will investigate the latest Italian labour market intervention policies in favour of the commitment to make working contexts inclusive for all. These policies concern job seeking mechanisms, activation measures and income support, training to promote employability among persons with disabilities, as well as interventions supporting business contexts. The Italian idea starts from the perspective driven by the awareness that the question of work is linked to personal well-being and the possibility of increasing social participation, which is a decisive dimension of the ICF classification. In Italy, for the first time in February 2017, the Madia Reform spoke of "Managers of integration processes for persons with disabilities", and this figure is mentioned among the other new strategies to be implemented with a view to the integration of persons with disabilities into the labour market. The tasks of this professional figure are very similar to the idea of Disability and Inclusion Management, theorised for the first time in the 1980s as a useful methodology for reconciling the right to inclusion in the labour market of persons with disabilities and chronic illnesses with the need for efficiency of businesses.
\end{abstract}

Keywords: pedagogic, prospects for inclusion, people with disabilities, labour market.

\section{Introduction}

Employment and occupational policies have been in the spotlight in Italy for some time now. In fact, as a characteristic feature of adulthood, a person's working condition has been the central focus of Italian legislators since the issue of the Constitution of the Republic, the incipit of which states "Italy is a democratic Republic founded on labour" (art. 1) ${ }^{1}$. The Constitution goes on to

\footnotetext{
* Full Professor in Methodologies of Teaching and Special Education at University of Bologna. E- mail: roberta.caldin@unibo.it.

${ }^{* *}$ Senior assistant professor (fixed-term) of Teaching and Special Education at University of Bologna. E-mail: valeria.friso@unibo.it.

The two authors have shared the theme of the project. However, it is specified that Roberta Caldin has drawn up paragraphs 1, 5 and Valeria Friso has drawn up paragraphs 2, 3, 4.

1 Italian Constitution, https://www.senato.it/documenti/repository/istituzione/costituzione.pdf [consulted on 03/01/2019].
} 
underline how work is not merely an "accessory" but an authentic right of any person: "The Republic recognises the right of all citizens to work and promotes those conditions which render this right effective" (art. 4).

At regulatory level, Italy has long considered the importance of persons with disabilities also being able to access the world of work, but the UN Convention on the rights of persons with disabilities, ratified in Italy in 2009 by Law No 18 of 3 March $2009^{2}$, certainly gave a new impetus to the issue.

The main article to which reference is made in this work is Art. 27, which states: "recognizes the right of persons with disabilities to work, on an equal basis with others; this includes the right to the opportunity to gain a living by work freely chosen or accepted in a labour market and work environment that is open, inclusive and accessible to persons with disabilities" (United Nations, 2006).

In signing the UN Convention, Italy undertook to establish an Observatory, the tasks of which include also the monitoring and promotion of inclusion, as well as more importantly - the maintenance of jobs by persons with disabilities. In Article 3 the Convention proposes the establishment of the Observatory, the functions of which include the monitoring and control of the implementation of the Convention itself. In addition to being a supranational text approved by 191 countries around the world, the novelty of the UN Convention text is that it is based on the International Classification of Functioning, Disability and Health (ICF), an innovative instrument developed by the World Health Organisation (WHO) in $2001^{3}$ and approved by the $54^{\text {th }}$ World Health Assembly (WHA), revising the previous International Classification of Impairments, Disabilities, and Handicaps published in 1980 by the WHO.

In this paper we will investigate the latest Italian labour market intervention policies in favour of the commitment to make working contexts inclusive for all. These policies concern job seeking mechanisms, activation measures and income support, training to promote employability among persons with disabilities, as well as interventions supporting business contexts. The Italian idea starts from the perspective driven by the awareness that the question of work is linked to personal well-being and the possibility of increasing social participation, which is a decisive dimension of the ICF classification.

\section{European situation and Italian situation}

The photograph of the European situation on the composition of the European work force in 2017 (Table 1) is interesting as it gives a clear idea of the number of persons this paper refers to. As concerns the number of persons

2 The full text of the law can be consulted on the website: www.osservatoriodisabilita.it/images/documenti/ratifica convenzione onu.pdf.

${ }^{3}$ To consult the full text of the ICF refer to the WHO text (2008). 
with disabilities aged between 20 and 64 in work, evidently there is a huge disparity between those who have and those who do not have a disability (Table $2)^{4}$, therefore the recommendations and actions to support integration into the labour market of persons with disabilities would appear useful in all European countries. Aware of this, during the Annual Convention for Inclusive Growth 2018 (ACIG) in April 2018 the European Commission proposed the European Pillar of Social Rights (EPSR) which sets out 20 principles, many of which refer specifically to the issue of integration into the labour market.

Table 1 - Labour force composition in Europe, 2017 Source: Eurostat, June 2018 https://ec.europa.eu/eurostat/statistics-explained/index.php?title=File:Labour_force_composition,_EU28, 2017 (thousand persons)-RYB18.png [consulted on 05/01/2019]

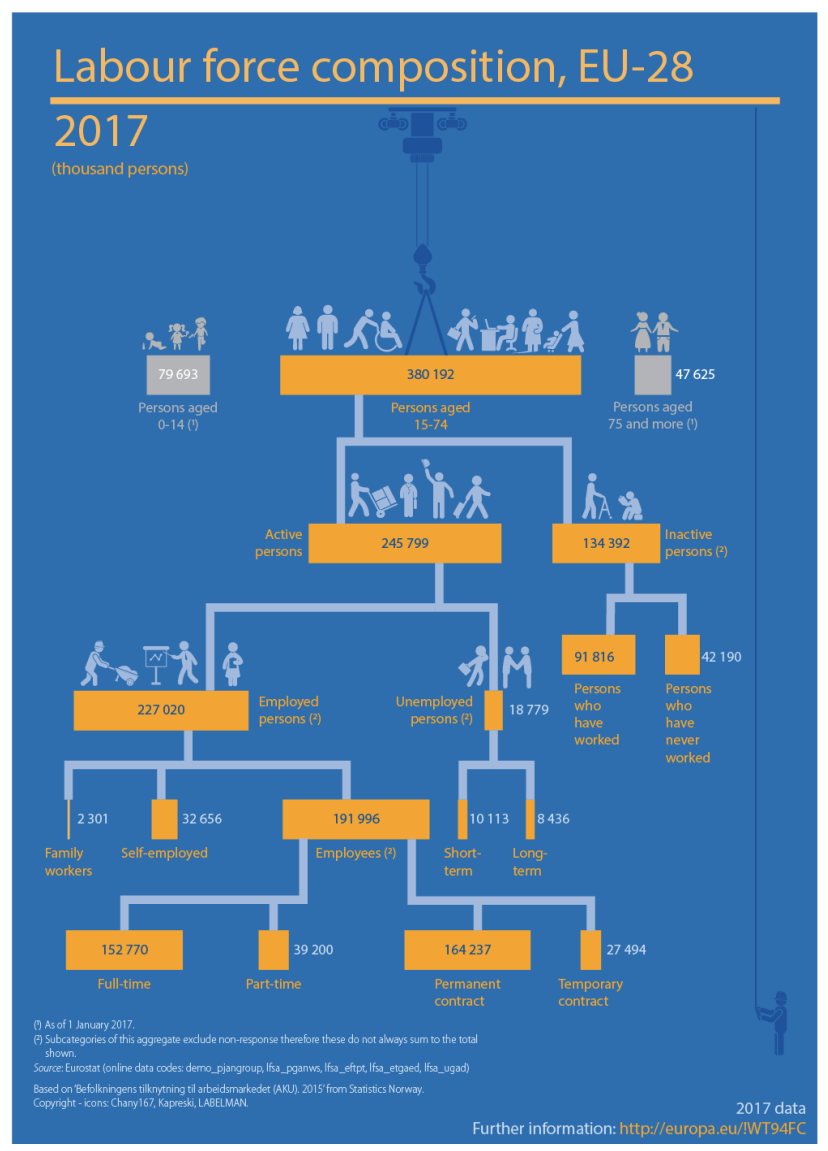

${ }^{4}$ The data in table 2 refer to 2011 , as they are the most recent currently available. 
Table 2: Persons aged between 20 and 64 at work and their health condition Source: Eurostat, 2011 http://appsso.eurostat.ec.europa.eu/nui/setupDownloads.do [consulted on 05/01/2019].

\begin{tabular}{|c|c|c|c|c|}
\hline & $\begin{array}{l}\text { Difficulty with } \\
\text { basic activities }\end{array}$ & \begin{tabular}{|l|}
$\begin{array}{l}\text { No difficulty with } \\
\text { basic activities }\end{array}$ \\
\end{tabular} & $\begin{array}{l}\text { Limitation of work due } \\
\text { to health conditions }\end{array}$ & $\begin{array}{l}\text { No limitation of work due } \\
\text { to health conditions }\end{array}$ \\
\hline European Union & 48.1 & 72.1 & 38.7 & 72.9 \\
\hline Belgium & 41.8 & 72.9 & 34.0 & 74.0 \\
\hline Austria & 61.1 & 80.1 & 48.4 & 80.7 \\
\hline Bulgaria & 30.9 & 67.1 & 18.0 & 67.3 \\
\hline Cyprus & 47.1 & 77.6 & 41.9 & 78.7 \\
\hline Croatia & 33.0 & 61.5 & 31.8 & 60.3 \\
\hline Denmark & 47.0 & 81.4 & 41.8 & 83.5 \\
\hline Estonia & 51.1 & 75.1 & 34.3 & 77.0 \\
\hline Finland & 61.9 & 79.5 & 51.4 & 81.0 \\
\hline France & 57.3 & 73.1 & 61.0 & 74.7 \\
\hline Germany & 52.5 & 77.2 & 36.2 & 77.8 \\
\hline Greece & 35.9 & 63.3 & 30.1 & 63.8 \\
\hline Ireland & 30.9 & 66.2 & 22.0 & 67.8 \\
\hline Iceland & 67.3 & 85.9 & 67.2 & 87.2 \\
\hline Italy & 46.1 & 63.7 & 37.6 & 64.0 \\
\hline Latvia & 51.9 & 69.5 & 41.8 & 69.6 \\
\hline Lithuania & 41.2 & 71.2 & 32.9 & 72.0 \\
\hline Luxembourg & 63.9 & 71.6 & 49.8 & 73.6 \\
\hline Malta & 35.0 & 63.9 & 30.4 & 65.5 \\
\hline The Netherlands & 43.0 & 82.9 & 39.7 & 83.2 \\
\hline Poland & 34.5 & 70.3 & 26.7 & 70.2 \\
\hline Portugal & 52.0 & 73.8 & 44.8 & 76.0 \\
\hline United Kingdom & 48.3 & 79.2 & 36.4 & 79.7 \\
\hline Czech Rep. & 39.0 & 74.5 & 35.1 & 75.5 \\
\hline Romania & 32.0 & 68.9 & 24.1 & 70.4 \\
\hline Slovakia & 32.4 & 69.2 & 29.5 & 70.2 \\
\hline Slovenia & 47.5 & 73.8 & 44.5 & 76.0 \\
\hline Spain & 44.9 & 64.2 & 34.3 & 65.9 \\
\hline Sweden & 69.0 & 82.6 & 64.0 & 83.4 \\
\hline Switzerland & 70.1 & 84.8 & 66.4 & 85.7 \\
\hline Turkey & 41.7 & 55.9 & 40.6 & 56.1 \\
\hline Hungary & 24.0 & 67.3 & 18.4 & 67.1 \\
\hline
\end{tabular}


Whether producing goods, knowledge or services, work has many functions in the lives of adults, including that of allowing them to participate in social purposes, which is a particularly important aspect in ICF terms as it specifically affects one of the dimensions of the international classification. Some authors have even stated the primacy of social services (of work activity) over profit ${ }^{5}$.

Certainly "work is a specific reality of humans, by which they dominate and transform the surrounding nature, bending it to the service of human life. As a person's specific experience, it contributes to their spiritual wealth and physical strengths" (Galli et al., 2000). Work however refers to the striving towards an objective and an activity which involves aspects of both constriction and selfrealisation. Work often determines a person's social role, governing many social interactions and also defining one's social status (Friso, 2013). A person's identity through their work activity is elevated as an essential component and a quality, and is also strengthened (Caldin, 2007).

As Lepri explains: "work, with all its renewed ambiguity, remains the central element in people's lives. Work is an experience we are prepared for and which we strive to achieve" (Lepri, 2009).

In Italy, concerning integration into the labour market, great importance is held by the national framework law no. 845/78, which led to the start of the first 'formazione in situazione' (on-the-job training) initiatives in Genoa, followed by Italian Law no. 68 of 12 March 1999. The law, "Rules on the right to work of persons with disabilities", states that companies must hire disabled workers with certified reduction in working capacity of more than $45 \%$ (33\% for workers with work-related disabilities).

In relation to the number of persons with disabilities who must be employed by companies, Law 68 was partly superseded by Law no. 19 of 27 February 2017 which triggered the requirement introduced by the Jobs Act for employers with between 15 and 35 employees to hire a disabled worker.

According to the amendments introduced by the Jobs Act to Law No. 68/1999, from 1 January 2018 employers are required to hire a person with disabilities if they have at least fourteen employees, thus no longer the sixteenth employee, and have sixty days to comply with the law.

The company is required to produce the Disabled Persons Information Note: this document must be submitted on-line to the competent provincial service, indicating the employment situation of the company - i.e. how many workers it has - to check the compliance in relation to the hiring of persons from protected categories or with disabilities. If the note is not submitted, a fine of 635.11 EUR is applied, as well as a further 30.76 EUR for every day of delay.

\footnotetext{
${ }^{5}$ For more detail on this current of thought refer to the work by Mounier 1947.
} 
Education Sciences \& Society, 2/2019, ISSN 2038-9442

Table 3 - Percentages of employment obligations updated by Italian law from 1 January 2018

\begin{tabular}{|l|l|}
\hline Company size & Mandatory inclusion of persons with disabilities \\
\hline from 15 to 35 workers & one worker with disabilities \\
\hline & \\
\hline from 36 to 50 workers & two workers with disabilities \\
\hline over 50 workers & a share of $7 \%$ must be reserved for workers with disabilities \\
\hline
\end{tabular}

A further amendment implemented from 2018 relates to the fact that persons with mental disabilities can only be hired with a specific named request by the companies; specifically via agreements. In fact, according to art. 11, companies programme the named recruitment of persons with disabilities, signing specific and appropriate agreements with the competent offices indicating the times and methods of hiring, vocational training, medium-long term probationary periods or fixed-term employment contracts, with the possibility to obtain facilitations as referred to in art 13 .

These facilitations also apply to employers who do not have an obligation to hire persons with disabilities and relate to:

- full tax exemptions for national insurance and social security contributions for a period of eight years for each worker with certified invalidity of over $79 \%$ or with mental and psychological disabilities, whatever the degree of invalidity;

- $50 \%$ tax exemptions for up to 5 years for each worker hired with reduced working capacities of between 67 and $79 \%$;

- partial lump-sum refund of the costs for adapting work stations to the operational possibilities of persons with disabilities with reduced working capacities of over $50 \%$ or the installation of teleworking technologies or the removal of architectural barriers.

The last data available on employment in Italy refer to April 2017, in which ISTAT recorded 22,998,000 employed persons. While these are the figures for people without particular needs, in Italy the underlying situation for young people and adults with disabilities was dramatic, indeed so much that as early as July 2013 the EU condemned the Italian Government and Parliament for not having applied the principles for fostering the inclusion of disabled persons in the labour market, breaching the obligations set forth in Directive 2000/78/EC of the Council of 27 November 2000, which gives a general framework for equal treatment in matters of employment and working conditions for the disabled.

\footnotetext{
${ }^{6}$ In the calculation the employer must consider all workers with a subordinate contract of employment, apart from some exceptions, such as cooperative workers, executives and other specific cases.
} 
The last comparison of employment figures and the condition of disability compared to non-disability in Italy dates back to 2013 (Table 4).

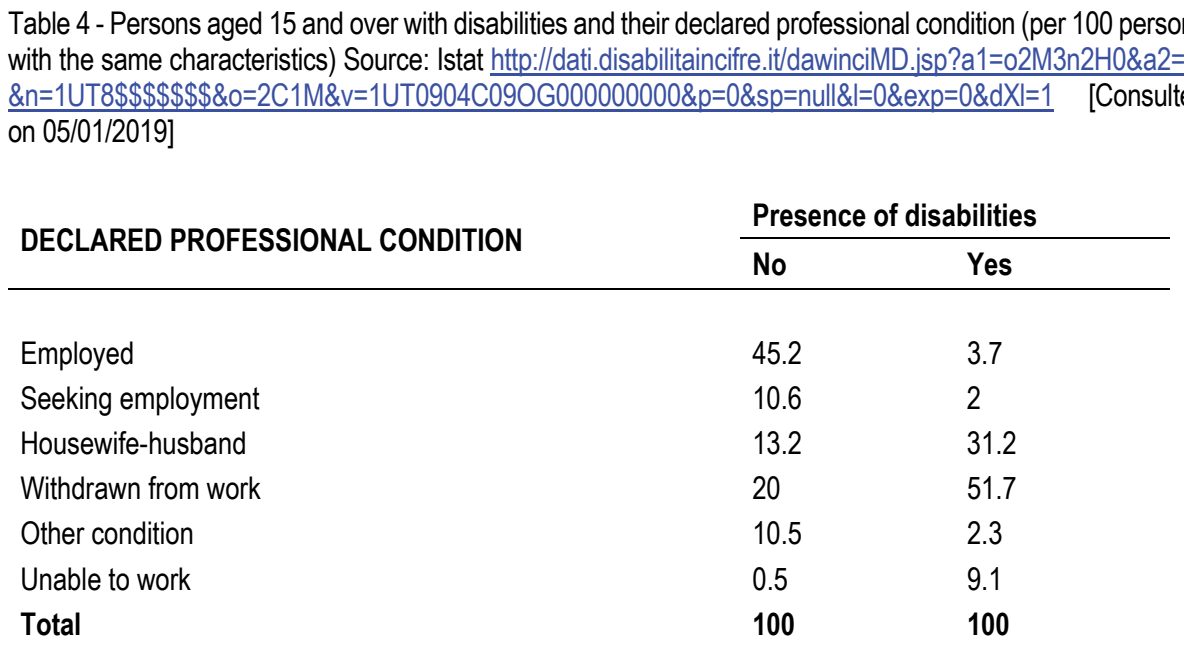

With Angeloni and Borgonovi (Angeloni et al., 2017: 63-64) we find that, unfortunately and despite the progress made in the legislative field, persons with disabilities continue to suffer from much higher unemployment rates than the rest of the population (Baldwin et al., 2005). We can therefore state that in Italy, despite some virtuous cases of companies that are inclusive and accessible to workers and clients with disabilities (Angeloni, 2013), the attitude of the business world to disability is still somewhat prudent and wary, and in the same way greater academic agreement on social inclusion studies continues to have difficulty in becoming established (Angeloni, 2011).

As is clear from the data, the commitment to access to employment by persons with disabilities must become a multi-disciplinary commitment. In this sense, Pedagogy is also called into question.

\section{The request for commitment}

Commitments to integration into the labour market require the training of an adult population that is aware of its own limits and resources. The Human Development Report reminds us that supporting a better development of the community means activating policies and strategies focusing efforts and attention in three areas linked to the world of work: 


\begin{abstract}
“creating work opportunities, ensuring workers' well-being and developing targeted actions.

The first area focuses on national employment strategies and seizing opportunities in the changing world of work, while the second area covers such important issues as guaranteeing workers' rights and benefits, expanding social protection and addressing inequalities. Targeted actions should focus on sustainable work, addressing imbalances in paid and unpaid work and interventions for specific groups - for example, for youth and people with disabilities" (UN, 2015:6)
\end{abstract}

While in Italy the process of integration of disabled people began over forty years ago - above all in schools, systematically and continuously - we cannot deny that, as explained, "it continues to show fragilities in various fields and due to often disregarded laws, confusion over the competences and responsibilities of those who should be the driving force of integration; the lack of available resources for implementing the legal provisions themselves" (Gelati, 2004: 528).

Investigating the situation today, we can see that part of the application of new rules on the mandatory hiring of workers with disabilities is being delayed, but luckily one glimmer of hope in this field was seen at the end of 2018. In the session of 7 November 2018, the Democratic Party MP Lisa Noja deposited two specific written Questions to the Minister of Labour and the Minister for Family and Disability, specifically asking about the application of Decree 151/15 and which actions they intended to undertake. The first Question $\left(4 / 01567^{7}\right)$ concerns the Guidelines, the second $\left(4 / 01568^{8}\right)$ the Database.

\footnotetext{
${ }^{7}$ The question text is as follows: "For information - considering that: legislative decree no. 151 of 14 September 2015, provides for the "Rationalisation and simplification of the procedures and requirements of citizens and businesses and other provisions relating to employment relationships and equal opportunities, implementing Law no. 183 of 10 December 2014"; Chapter I of the above decree sets significant measured for the "Rationalisation and simplification of recruitment of persons with disabilities", partly intervening in the previous law, no. 68 of 12 March 1999, a fundamental provision for the integration into the labour market for persons with disabilities; Article 1 sets the assumption for the concrete application of these laws as the definition of "guidelines" relating to targeted recruitment of persons with disabilities; these indications represent an essential conceptual and operational reference for employment services, for the regions and for the persons with disabilities; currently these "guidelines" have not yet been issued -: if the Ministry of Labour and Social Policy is drafting this important document; if, in drafting it, as per the UN Convention on the rights of persons with disabilities approved by Italian Law no. 18/2009, the involvement has been sought of the organisations representing persons with disabilities; if and by when the Ministry of Labour and Social Policy intends to define such measures laid down in law for over three years."

${ }^{8}$ The question text is as follows: "For information - considering that: legislative decree no. 151 of 14 September 2015, provides for the "Rationalisation and simplification of the procedures and requirements of citizens and businesses and other provisions relating to employment relationships and equal opportunities, implementing Law no. 183 of 10 December 2014";
} 
As pedagogists, the question we ask in relation to these regulatory developments is, how can we interpret these normative provisions with a view to promoting the integration into the labour market of persons with disabilities, seen and considered holistically and not perceived merely as numbers?

\section{The new commitment and possible pedagogic perspectives}

From a pedagogic point of view, there must be vigilance, starting from the identification of those elements which do not facilitate integration into the labour market in order to be able to work on the cultural, political and social elements. Various international research works indicate the main "inhibitors" to integration into the labour market which should, therefore, be considered by professionals working on the facilitation of integration into the labour market. These may run from the idea that a person may find themselves in difficulty in performing their work o the worry about the impact of drugs and health care (Henry et al., 2004). Potential negative attitudes from employers or their own family may also become inhibitors to be considered in the integration process 9 . On the other hand, facilitators can also be identified in some instruments such as integration through prior traineeships (Luecking et al., 2000) - provided that the traineeship does not become a surrogate of integration - or thanks to the perception of self-efficacy offered by previous professional experiences (Blitz et al., 2006). School skills along with professional abilities can also act as

\footnotetext{
Chapter I of the above decree sets significant measured for the "Rationalisation and simplification of recruitment of persons with disabilities" partly intervening in the previous law, no. 68 of 12 March 1999, a fundamental provision for the integration into the labour market for persons with disabilities; Article 8, amending Article 9 of Italian Law no. 68 of 12 March 1999, intervenes in the strategic aspect of knowledge and the collection of data on integration into the labour market, indispensable for the formulation of congruent active policies and services; in this sense Article 8 states: "In order to rationalise the systematic collection of data available on targeted recruitment, to simplify requirements, strengthen controls and improve the monitoring and evaluation of the interventions referred to in this Law, in the active and passive policies database referred to in Article 8 of decree-Law No 76 of 28 June 2013, converted with amendments from Law no. 99 of 9 August 2013, a specific section has been established, without any new or increased charges for public finance, entitled "Targeted recruitment database" which collects information on obliged public and private employers and workers concerned"; currently no process is active relating to the establishment of this "Targeted recruitment database" -: what is the state of the art and which are the actions and initiatives targeting the implementation of the "targeted recruitment database"; what are the foreseeable times for the full availability of data and related analytical instruments".

${ }^{9}$ These elements referring to attitudes, along with other indicators, were investigated in a research project in 2011 by Lee Abdullah, and are reported in the text: Heymann J. et al., (2014). Disability and Equity at Work. Oxford University Press.
} 
facilitators, such as the gradualness of integration, the progressive increase in the complexity of the tasks or the adoption of initially shorter and flexible working hours (ISFOL, 2011).

In addition to attention towards these inhibitors, in this historical phase the pedagogic perspective must focus on at least three elements: the construction of a services network, attention to the passage from the education and training system to the world of work and the promotion of pedagogical competences in the construction of the profiles of figures in charge of fostering inclusion processes in the company.

\section{The services network}

One pedagogic constructive perspective we can identify in the research activities we conduct concerns the importance of promoting the development of networks between local services and businesses. These networks can help to identify aspects and situations which contribute to the development of integration into the labour market. When systematised, these research works may lead to the investigation of whether and how far the "preparatory" work for the inclusion of workers - "learning to work" - affects the increase in recruitment figures (European Strategy 2010-2020). The authors are working in this direction, convinced of the increasing urgency to offer strategic and coordinated responses to the task of making networking tangible, not only in logistic/economic terms but, above all, offering tried-and-tested professional competences that integrate academic skills (Caldin et al., 2012). The labour market requires information and training centres which run, for example, training courses for company tutors - key figures in facilitating inclusion processes - which activate and implement instruments for monitoring the transition from school to work, involving both professionals and recipients in the project right from its initial phases.

This is certainly an innovative path, in which the potential areas and markets where the results of the projects are applied contribute to the experimentation of forms of integration into the labour market in various fields, from the more traditional to more diversified sectors (small, local trades, situations facilitated by technologies, etc.). In this way integration becomes an authentic educational process which is transformed into real inclusive education provided it is accompanied by a special way of thinking (Montuschi et al., 2004), which makes the whole community committed and responsible, extending the sphere of social participation of persons with disabilities without compromising their own major role in their own life project, with a view to increasingly close exchange in both theoretical and operational terms (Caldin et al., 2004). 
Precisely in this sense, we think it is important to tackle the issue of work for disabled persons right from a young age, thus during the adolescent years at school and immediately after the end of the school experience (Caldin, Cavalluzzo, 2007) o progress in this field, it is indispensable to conduct research programmes which identify effective and efficient processes that foster social inclusion and which understand work as a capability that everyone has a right to, and which the whole community must guarantee, through the assumption of widespread, differentiated responsibility (Sen, 2005).

While much has already been done, and often the direction taken by companies, institutions and associations is the same, there is however no harmonisation of the methods, common scheduling of times and overall choice of spaces. Research and training are increasingly required to help these elements to proceed together towards authentic inclusion, strengthening and rendering concrete the willingness which often remains unable to assure actual design and implementation.

\section{Transition from school to work}

In pedagogic terms, one of the elements most investigated currently by researchers of integration into the labour market is how this is linked - or unlinked - to the previous life phases. Over the years, various experiments have sought to bring the world of education and training closer to that of work, not only for persons with disabilities but for all young people.

One of the methods chosen in recent years in Italy, alongside internships, traineeships and other existing forms of school-work cooperation is that known as "alternanza scuola-lavoro" ("school-work alternation"). During this period students are required to learn the specific competences of their own studies not only at school but also in an actual working context. A real, concrete situation is certainly an element that facilitates learning also for young people with disabilities (Lepri et al., 2000). In particular in this method we may identify the facilitation of achieving some results which are particularly useful for an aware approach to the labour market, which could mitigate the situation - increasingly common in times of crisis - in which young people with disabilities return home without a job at the end of the training period. Some of the expected results for young people participating in these training paths include:

- Knowledge of professional and training fields;

- Awareness of one's own knowledge, skills and motivations;

- Strengthening of skills relating to independence, enhancement of knowledge, skills and abilities already possessed and the acquiring of specific skills; 
- Development of the personal awareness of one's own individual project;

- Definition of a transition project based on real experiences, competences put into play and achievable professional and social skills which are sustainable over time;

- Contribution to the development of a professional identity;

- Through work, the development of concepts of independence, selfdetermination and active participation.

Obviously, when the system promotes this approach, results are obtained not only at individual level but also in relation to the people close to them, including relatives, as well as for the system itself. For example, some broader expected results may relate to:

- Supporting schools and social-health services in drafting "personalised educational projects" and "life projects" for the young people involved in the project;

- Strengthening and qualifying the relations with Employment Services, in particular the local job centres which run subsequent employment integration paths in accordance with Italian Law no. 68/99;

- Raising awareness among the labour market of the issues of social and professional inclusion of persons with disabilities;

- Enhancing the territorial network and improving the degree of interaction among the various stakeholders.

To ensure that these results are achieved in the most effective manner possible, the commitment cannot be sporadic, but rather multiannual programmes must be run which ensure continuity and strengthen, qualify and harmonise the different responses which must be made available to young people with disabilities and their families, ensuring the transparency and enhancement of the role of each stakeholder. Translating these projects into actions must be based on co-construction, understood as the key tool for implementing effective, high-quality interventions, ensuring the liaison between the different management levels involved, the different financial sources and different instruments, as indicated in the European strategy for social inclusion. In particular, multiannual projects can support the availability of broader individual paths, unbound by single years and therefore able to accompany young people continuously from the final years of school and vocational training through to their integration into the labour market.

Moreover, to guarantee projects which effectively respond to complex needs, actions must be taken to foster the integration of the various actions for each young person, through the involvement of all the competent services and stakeholders involved, right from the first stages of the project (in the Italian case, these are: the schools attended, social and health services in charge of the young people and their families; businesses; associations for persons with 
disabilities; accredited vocational training centres running the projects). In this case the actions must be undertaken respecting the different competences and roles of each stakeholder, to ensure that all strategies for accompanying the young people towards the world of work can be effectively activated.

In Italy, the issue of disciplinary orientation and orientation is becoming more and more widespread. The reflections that are taking place are leading high schools to think about the theme of orientation in terms of selfdetermination. On these issues a great contribution to scientific and theoretical reflection is offered by the Italian Orientation Society (https://www.sioonline.it) which theorizes and collects empirical data that dominate how orientation allows to greatly reduce the habit of organizing standardized activities, the same for all. If orientation is able to give space to the specificities, to the uniqueness of people, to their right to receive personalized attention, it clearly becomes an essential driving force towards the inclusion of all in the world of work.

The pedagogic competences of business professionals with inclusion responsibilities

Another pedagogic element to be considered in order to promote inclusive contexts in the labour market is that of training figures to support the processes for integrating and maintaining persons with disabilities in the labour market.

In Italy, for the first time in February 2017, the Madia Reform spoke of "Managers of integration processes for persons with disabilities", and this figure is mentioned among the other new strategies to be implemented with a view to the integration of persons with disabilities into the labour market ${ }^{10}$. These professional figures, according to article 39-Ter, guarantee the effective integration of persons with disabilities into the working environment Paragraph 2 lists their specific functions:

"a) Oversees relations with the department of integration of persons with disabilities into the labour market at the competent local job centre, as well as the territorial services for targeted inclusion;

b) Having sought the opinion of the occupational physician in their own administration and where required the technical committee referred to in Law no. 68/99, ensures the organisation and, where necessary, makes

${ }^{10}$ The Madia Reform not only creates the figure of "Manager of integration into the labour market" but also refers to the creation of a database and the establishment of a National Council for integration of persons with disabilities into the labour market - established within the Public Function department of the Presidency of the Council of Ministers, without new or increased costs for public finance (Italian Legislative Decree 165/2001). 
available the technological solutions to facilitate integration into the labour market, also for the purpose of the required, reasonable accommodations referred to in article 3, paragraph 3-bis, of Legislative Decree no. 216 of 9 July 2003;

c) Monitors the implementation of the integration process, recording and reporting any situations of hardship or difficulty in integrating to the competent services (D.lgs 165/2001)".

This text was then transformed into Legislative Decree No 75 of 25 May 2017, amending Legislative Decree no. 165 of 30 March 2001, pursuant to articles 16, paragraphs 1 , letter a), and 2, letters b), c), d) and e) and 17, paragraph 1, letters a), c), e), f), g), h), l) m), n), o), q), r), s) and z), of Italian Law no. 124 of 7 August 2015, on the reorganisation of the public administrations. (17G00089) (OJ General Series 130 dated 07-06-2017) ${ }^{11}$.

The tasks of this professional figure are very similar to the idea of Disability and Inclusion Management, theorised for the first time in the 1980s as a useful methodology for reconciling the right to inclusion in the labour market of persons with disabilities and chronic illnesses with the need for efficiency of businesses. This line of thinking, and this practice, were soon commonplace above all in the United States, Canada and Northern Europe, aiming to involve businesses in the process of improving working conditions and the active promotion of the possibility of workers with disabilities to keep their jobs (Aimone, 2017; Bruzzone, 2017; Friso, 2018). In Italy this issue has being tackled only in recent years, now deemed a necessary instrument for implementing the commitments entered into with the approval of the UN Convention on the rights of persons with disabilities (L.18/09). For this purpose, the experimental plan included in the two-year plan for the rights of persons with disabilities approved by the $5^{\text {th }}$ National Conference of the National Observatory on the condition of persons with disabilities, not only provides for the establishment of a joint body, such as the Technical business observatory/unit, but also includes the creation of this professional figure (which, depending on the various languages, is called: Manager of integration into the labour market, job coach, tutor, disability manager).

As Consuelo Battistelli, Diversity Engagement Partner for IBM Italy and Vice President of Abilitando, states, this figure was born as a creative facilitator, with the task of building solutions to support the autonomy of persons with disabilities in the different spheres of their everyday lives. It is therefore a builder of networks, services and solutions which, necessarily starting from the needs of the persons with disabilities, makes available instruments for creating a uniform, coordinated vision to improve the quality

\footnotetext{
${ }^{11}$ http://www.gazzettaufficiale.it/eli/id/2017/06/07/17G00089/sg.
} 
of local policies. Its aim is to foster urban accessibility, social and health coordination, inclusion in schools, the labour market and tourism, by overcoming the boundaries of the services and enhancing the professional skills existing in the territory.

\section{Conclusions}

The process of integration into the labour market is important because it is part of a broader process of social inclusion. Social inclusion through traineeships or employment may not be realistically possible for many of the persons who are currently employed in protected situations ${ }^{12}$.

Returning to Gardou, we should recall how this author, a reference for many operators working in the field of disability, identified four indispensable conditions for persons with disabilities to be able to fully play their role in the human community:

- Recognition: "no person exists without another recognising them as such in their difference";

- Autonomy: "no person exists without another accompanying them to conquer autonomy";

- Rights: "no person exists without another recognising their rights and dignity";

- Saying and acting: "no disabled person exists who can fulfil themselves as a person without a society which translates its democratic intentions of inclusion into actions" (Gardou, 2006: 39).

Also in processes of integration into the labour market, therefore, the central focus must be on the disabled person, their well-being and their progressive acquiring of competences and skills within the work activity that should distinguish any adult. Starting from this assumption, integration into the labour market will for some become the well-deserved and desired goal of their growth path. For others, on the other hand, integration into the labour market could be an experience in which it is hard to balance benefits and negative effects (lack

12 In Italy forms of "protected" work are defined in art. 52 of Italian Legislative Decree 163/2006: protected workshops and protected work programmes.

This introduced a derogation to the normal conditions of competition in favour of legal entities and programmes promoting the integration or re-integration, of disabled persons into the labour market. The pursuit of a social objective through public contracts thus takes place, in the case of art. 52, through the creation of a participation reserve working both in subjective (protected workshops) and objective terms (protected programmes), in both cases characterised by a majority of disabled persons employed. This reserve helps to safeguard to position of disabled people, placing them beyond exclusively competitive mechanisms". 
of involvement, isolation, performance of activities they dislike, etc.). For others again, if the integration into the labour market is too quick it may risk compromising the gradual confidence and knowledge the person is acquiring at work, but which do not yet allow them to be ready for a context in which they have to be able to care for themselves even before caring for their productive activity. Finally, for those who still have to develop motivation to work and an attitude towards interacting with the surrounding context, work inclusion can become that perceived on a daily basis in a protected workshop.

Work, with its different meanings that are personal to every one of us, comes with many very different methods in terms of productivity, quality, autonomy, relational skills, compliance with rules, etc., but for everyone it is an activity that requires commitment, responsibility, gratification (and correction) as well as financial consideration. Work activities are a potential bridge for recognising oneself as an adult, for performing activities autonomously away from the family, for being able to feel important with and for other people. It offers the possibility to choose the priorities, organisation and instruments for selffulfilment. Understood in this way, for many people the world of work is a context in which, for the first time, they can be of help to others, they can gradually discover which task/s they prefer, they can succeed in performing tasks through the indispensable creation of tools which help to enhance their own resources. Last, but not least, work activity allows people to build relationships, friendships and collaborations which do not end at the end of the working day, but which allow them to offer completeness, motivation and further life objectives to special people, not because they are different but because they are able to enhance and enrich the persons working alongside them.

\section{Bibliographic references}

Aimone P. M. (2017). Come il disability manager cambierà l'approccio all'inclusione lavorativa. Www.superando.it/2017/04/20/come-il-disability-manager-cambieralapproccio-allinclusione-lavorativa/ [Consulted on 22/06/2018].

Angeloni S. (2011). Il Disability Management Integrato: Un'Analisi Interdisciplinare per la Valorizzazione delle Persone con Disabilità. Roma: Rirea.

Angeloni S. (2013). Accessible tourism in the Italian destination, International Conference on Tourism \& Hospitality Management, Athens, 27-29 June, 8-28.

Angeloni S., \& Borgonovi E. (2017). Laboro ergo sum. Quando il lavoro abilita l'uomo. Sviluppo \& Organizzazione, 1: 54-66.

Baldwin M.L., \& Johnson W.G. (2005). A critical review of studies of discrimination against workers with disabilities. In: W.M. Rodgers III (Eds.). Handbook on the Economics of Discrimination. Cheltenham: Edward-Elgar. 
Blitz C., \& Mechanic D. (2006). Facilitators and barriers to employment among individuals with psychiatric disabilities: A job coach perspective. Work, 26: 407419.

Bruzzone S. (2017). Il Disability Management come approccio inclusivo, oltre la gestione delle risorse umane. ADAPT-University Press.

Burns T., \& Catty J., \& Becker T., \& Drake R.E., \& Fioritti A., \& Knapp M., \& White S. (2007). The effectiveness of supported employment for people with severe mental illness: a randomised controlled trial. The Lancet, 370(9593): 1146-1152.

Caldin R., \& Cavalluzzo M.R. (2007). Disability and work inclusion Mida. Modello per l'inserimento dell'alunno disabile in azienda. In atti International Conference General Assembly IAEVG. Guidance and diversity. Research and application, Padova.

Caldin R., \& Friso V. (2012). Quale lavoro per le persone con disabilità, oggi, in Italia? Studium Educationis, 3: 37-57.

Caldin R., \& Friso V. (Eds.) (2012). Pensare, fare, diffondere cultura inclusiva. Riflessioni ed esperienze nel Master dell'Università di Padova "Disabilità e interventi inclusivi nelle istituzioni e nel territorio”. Padova: Padova University Press.

Caldin R., \& Succu F. (Eds.) (2004). L'integrazione possibile. Riflessioni sulla disabilità nell'infanzia, nell'adolescenza e nella vita adulta. Lecce: Pensa MultiMedia.

Callegari L. (2012). Aziende solidali e lavoratori disabili quando le strutture organizzative sono prossime alle persone. Bologna: A.I.L.e S. (Associazione per l'Inclusione Lavorativa e Sociale).

Camera dei Deputati (2012). Relazione sullo stato di attuazione della legge recante norme per il diritto al lavoro dei disabili (Anni 2012 e 2013). http://bw5.cilea.it/bw5ne2/opac.aspx?web=ISFL\&opac=Default\&ids=18912. [Consulted on 09/05/2018].

Chassot Benincasa Meirelles M., \& Roberto D., \& Friso V. (2017). A Educação Especial no contexto italiano: o projeto de vida, da escola à vida adulta. Revista Educação Especial. 30: 189-202.

Corte di giustizia dell'Unione europea (2013). Inadempimento di uno Stato - Direttiva 2000/78/CE - Articolo 5 - Istituzione di un quadro generale per la parità di trattamento in materia di occupazione e di condizioni di lavoro - Disabili - Provvedimenti di trasposizione insufficienti. http://curia.europa.eu/juris/document/document.jsf;jsessionid=9ea7d2dc30db595dce9c7 eac40eaa9f0b99dba629708.e34KaxiLc3qMb40Rch0SaxuLbNb0?text=\&docid=139105 \&pag eIndex $=0 \&$ doclang $=i t \&$ mode $=$ req\&dir $=\& o c c=$ first\&part $=1 \&$ cid $=362634$. [Consulted on 09/01/2019].

Elia G. (2001). Percorsi formativi, dinamiche sociali e pedagogia speciale. Studium Educationis, 3: 623-632.

Eurostat (2014). Situation of people with disabilities in the EU. http://www.condicio.it/allegati/ 157/Eurostat_Statistiche2011_eng.PDF. [Consulted on 09/01/2019].

Friso V. (2013). Inclusione sociale, lavoro e capability. Lecce: Pensa Multimedia. 
Friso V. (2017). Disabilità, rappresentazioni sociali e inserimento lavorativo. Percorsi identitari, nuove progettualità. Milano: Guerini Scientifica.

Friso V. (2018). Disability Management. Studium Educationis, 3: 125-128.

Friso V., \& Caldin R. (2014). Capability, work and social inclusion. Procedia, Social \& Behavioral Sciences, 116: 4914-4918.

Galli N., Bruno M. (2000). Pedagogia della famiglia ed educazione degli adulti. Milano: V\&P Università.

Garcia V.G. (2014). Panorama da inclusão das pessoas com deficiência no mercado de trabalho no Brasil. Revista Trab. Educ. Saúde, 12(1): 165-187.

Gardou C. (2006). Diversità, vulnerabilità e handicap. Per una nuova cultura della disabilità. Trento: Erickson.

Gelati M. (2001). Handicap e vita adulta. Studium Educationis, 3.

Gelati M. (2004). Educazione e integrazione. Percorsi storici possibili. Disabilità, Integrazione e pedagogia speciale, 3: 527-535.

Henry A.D., \& Lucca A.M. (2004). Facilitators and barriers to employment: The perspectives of people with psychiatric disabilities and employment service providers. Work, 22: 169-182.

Heymann J., \& Stein M.A., \& Moreno G. (2014). Disability and Equity at Work. Oxford: Oxford University Press.

ISFOL (2011). Le prospettive di impiego delle persone con disabilità psichica: opportunità e barriere nei contesti aziendali. http://isfoloa.isfol.it/jspui/bitstream/123456789/1380/1/Isfol_FSE197.pdf [Consulted on 7/01/2019]

Jäckel D., \& Kupper Z., \& Glauser S., \& Mueser K. T., \& Hoffmann H. (2017). Effects of sustained competitive employment on psychiatric hospitalizations and quality of life. Psychiatric services, 68(6): 603-609.

Kuznetsova Y., \& Betul Y. (2017). Inclusion of persons with disabilities in mainstream employment: is it really all about the money? A case study of four large companies in Norway and Sweden. Disability \& Society, 32(2): 233-253.

Lepri C. (2009). L'esperienza lavorativa nel processo di formazione e maturazione delle persone con disabilità. In Piano Nazionale di formazione e ricerca del Ministero della Pubblica Istruzione. Uno sguardo oltre la scuola. Progetto integrato per favorire un efficace orientamento lavorativo degli alunni con disabilità. Belluno: DBS, pp. 17-19.

https://www.alternanzaescuola.it/Doc/XSito/Linee $\% 20$ Guida $\% 20 \mathrm{e} \% 20$ Vademecu m/alternanzascuolalavoro_disabilit.pdf [Consulted on 7/01/2019].

Lepri C. (2011). Viaggiatori inattesi. Appunti sull'integrazione sociale delle persone disabili. Milano: FrancoAngeli.

Lepri C., \& Montobbio E. (2000). Chi sarei se potessi essere. La condizione adulta del disabile mentale. Tirrenia: Edizioni Del Cerro.

Lepri C., \& Montobbio E. (2003). Lavoro e fasce deboli. Strategie e metodi per l'inserimento lavorativo di persone con difficoltà cliniche o sociali. Milano: FrancoAngeli.

Luecking R., \& Fabian E. (2000). Paid internships and employment success for youth in transition. Career Development for Exceptional individuals, 23(2): 205-221. 
Mainardi M. (2008). Projets éducatifs individualisés et prise en charge institutionelle. Les enjeux du partenariat interne et au travail d'équipe quant à la qualité percue de l'opératuionnalisation des projets déclarés. Jounal Européen d'Education Sociale, 14/15: 83-102.

Montobbio E., \& Navone A.M. (2003). Prova in altro modo. L'inserimento lavorativo socio assistenziale di persone con disabilità marcata. Pisa: Edizioni del Cerro.

Montuschi F. e Caldin R. (2004). Introduzione. Studium educationis, (3): 509-510.

Moody L., \& Saunders J., \& Leber M., \& Wójcik-Augustyniak \& M., Szajczyk M., \& Rebernik N. (2017). An exploratory study of barriers to inclusion in the European workplace. Disability and rehabilitation, 39(20): 2047-2054.

Programma delle Nazioni Unite per lo sviluppo (UNDP - United Nations Development Programme). Human Development Report 2015: work for human development.

Rutelli P., \& Agus M., \& Caboni R. (2007). Lavoro e identità psicosociali. Sicurezza, flessibilità e precarietà. Milano: FrancoAngeli.

Sen A. (2005). Justice and human disabilities, Laurea Honoris Causa dell'Università di Pavia.

Società Italiana di Orientamento https://www.sio-online.it.

UE, (2018) Pilastro Europeo dei Diritti Sociali (EPSR). https://ec.europa.eu/commission/sites/beta-political/files/social-summit-europeanpillar-social-rights-booklet it.pdf [Consulted on 7/01/2019].

United Nations (2006). Convention on the Rights of Persons with Disabilities (CRPD). https://www.un.org/development/desa/disabilities/convention-on-the-rights-ofpersons-with-disabilities.html [Consulted on 09/01/2019].

United Nations (2015). Development Programme, Human Development Report 2015. Work for Human Development. New York: U.N.D.P.

United Nations (2016). Development Programme, Human Development Report 2016. Human Development for Everyone. New York: U.N.D.P.

United Nations (2017). Sustainable Development Goals; Available from: https://sustainabledevelopment.un.org/sdgs [Consulted on 09/01/2019].

Viering S., \& Jäger M., \& Bärtsch B., \& Nordt C., \& Rössler W. \&, Warnke I., \& Kawohl W. (2015). Supported Employment for the reintegration of disability pensioners with mental illnesses: a randomized controlled trial. Frontiers in public health, 3: 237.

Vuckadin M., \& Schaafsma F.G., \&Westerman M.J., \& Michon H.W., \& Anema J.R. (2018). Experiences with the implementation of Individual Placement and Support for people with severe mental illness: a qualitative study among stakeholders. $B M C$ psychiatry, 18(1): 145.

WHO \& World Bank (2011). World Report on Disability 2011, WHO: Geneva available at http://www.who.int/disabilities/world_report/2011/en/index.html [Consulted: 09/01/2019].

World Health Organization (2000). The world health report 2000: health systems: improving performance. World Health Organization.

World Health Organization (2001). International classification of functioning, disability and health. Available from: http://www.who.int/classifications/icf/en/ [Consulted on 09/01/2019]. 